Acta Technologica Agriculturae 1

Nitra, Slovaca Universitas Agriculturae Nitriae, 2018, pp. 33-37

\title{
MONITORING OF LITTER QUALITY AND TEMPERATURE IN BREEDING OF FATTENING CHICKENS
}

\author{
Štefan BOĎO*, Roman GÁLIK
}

Slovak University of Agriculture in Nitra, Slovak Republic

\begin{abstract}
This paper is focused on monitoring of the outside temperature and humidity, together with microclimate conditions in a hall in order to investigate the impacts on fattening chickens during the winter period, the litter temperature and its quality, as well as stocking density. The outdoor and indoor temperature was monitored by means of Comet logger $R 3120$; the litter temperature measurement was performed with use of a non-contact thermometer Raytek Raynger ST. To determine the stocking density, the Guide TP8S thermographic camera was utilised. Stocking density was evaluated on the basis of obtained thermographic images. By monitoring of the litter quality, we achieved an average of 1.6 on the $10^{\text {th }}$ day and 1.5 on the $20^{\text {th }}$ day of fattening. Stock density was 1.1 on the $10^{\text {th }}$ day and 2.1 on the $20^{\text {th }}$ day. Comparing the $P$ values and the significance level $\alpha(0.05)$, we found that the $P$ value was $(0.000)<\alpha(0.05), R-0.622, R^{2}-0.39$ on the $10^{\text {th }}$ day. This value is a result of comparison of the litter temperature and its influence on its quality. By comparison of stocking density and its impact on the litter quality, the $P$ value was $(0.000)<\alpha(0.05)$, $R-0.916, R^{2}-0.84$. When comparing the temperature of the litter and its influence on stocking density, the $P$ value $(0.000)<\alpha$ (0.05), $R-0.711, R^{2}-0.505$. These values indicate that the observed indicators are strongly statistically dependent on the observed days. By comparison of the litter quality on the $10^{\text {th }}$ and $20^{\text {th }}$ day, a statistically significant difference $(0.000<0.05)$ was observed, as well as by comparison of the litter temperatures on the $10^{\text {th }}$ and $20^{\text {th }}$ day $(0.024<0.05)$.
\end{abstract}

Keywords: broiler; litter temperature; litter quality; air temperature; air humidity

The litter quality and appropriate microclimate conditions belong to the key factors in cost and profit assessments. Considering the chicken fattening, it is necessary to ensure the appropriate temperature and humidity according to the hybrid type during the first period of fattening lasting approximately for 14 to 21 days. Regarding the second part of the fattening process, it is important not to exceed the temperature value of $25^{\circ} \mathrm{C}$ and to maintain the relative humidity below $70 \%$ by means of intensive air circulation. These values are achievable only if the values of harmful gases are not exceeded (Tančin et al., 2013). Taking this issue into account, the value of occupation of the breeding area, which is stated either in animal units per $1 \mathrm{~m}^{2}$ of the floor area, or is obtained from the load - the stocking density of the breeding area given in $\mathrm{kg}$ of live weight at the end of the fattening period, is important. This issue is regulated by the Council Directive 2007/43/ EC, which has been adopted by the Slovak Republic via Regulation no. $275 / 2010$ from the $9^{\text {th }}$ of June, 2010. Poultry suffers from high temperature stress during the summer heat. This leads to a reduction in production and an increase in risks of illnesses and death. In general, the neutral temperature ranges between $13{ }^{\circ} \mathrm{C}$ and $24{ }^{\circ} \mathrm{C}$. At temperatures between $24{ }^{\circ} \mathrm{C}$ and $29{ }^{\circ} \mathrm{C}$, the feed consumption is slightly reduced and further decreases at temperatures from $29^{\circ} \mathrm{C}$ to $32^{\circ} \mathrm{C}$.

When the temperature rises to $35{ }^{\circ} \mathrm{C}$, the feed intake significantly decreases and the mortality increases especially in fattening chickens. The air heating within the object is caused by heat transfer from the animals, litter fermentation, and, especially, overheated ceiling and walls (Tančin et al., 2013). The dry litter has, on the other hand, a lower density and better thermal isolation properties influencing the comfort of poultry when lying. The humid environment of aggressive pollutants creates higher hygienic risks for both animals and humans and reduces the lifetime of buildings (Reichstädterová et al., 2013). The amount of heat produced by animals is determined primarily by its live weight and its activity (Bessei, 2006). If the animal density is high in the area, temperature may increase to hazardous levels, because more metabolic heat is produced, to which the hall ventilation might not be customised, which proved to be true especially for older types of halls or reconstructed halls (Pogran et al., 2011). This is dangerous in case of insufficient ventilation or non-ventilated places with warm air (Karandušovská et al., 2009). According to Knížatová et al. (2009), not only the temperature, humidity and $\mathrm{pH}$ but also lifetime (of the used litter) is important. The measurement of the individual litter quality parameters results in enormous animal stress (Weaver and Meijerhof, 1991). As reported by Butcher and Miles (2015), the optimum humidity of the litter ranges from $25 \%$ to $35 \%$ of relative humidity. One possibility of increased litter moisture can be related to feed composition. High salt content increases water consumption (Ritz et al., 2009). The photo-camera can be used for undisturbed welfare broiler observation, followed by evaluation of taken images by using of software (Kashiha 
et al., 2013). Despite the fact that animals live their lives, although short, in a strict defined environment, they should not be subjected to any suffering (Webster, 1994). The European Union also ensures that the scientific and technological progress is brought into line with animal welfare in economic prosperity (Communication from the Commission to the European Parliament, the Council and the European Economic and Social Committee on the European Union Strategy for the Protection and Welfare of Animals 2012-2015, 2012). The aim of our work was to monitor the microclimate conditions in the hall for fattening chickens and, on the basis of the results, to point out their impact on the litter quality, respectively, the density of animals, and to propose the measures for improvement of animal welfare at the selected farm.

\section{Material and methods}

The work was focused on monitoring of outdoor temperature and humidity during the winter period, air temperature in the hall, litter temperature, its quality and animal density in the hall. We followed the guide's recommendations of Ross broiler management manual (2009). For the litter quality assessment, a subjective three-stage evaluation system determined by Weaver and Meijerhof (1991) was utilised: if the litter was dry and hard, it was given the value of "1"; if it was moist and flexible, it was given the value of " 2 "; and if it was wet, it was given the value of " 3 ". A subjective method for assessing the density of poultry using a thermographic method was used to determine all the areas with high density. If stocking density was high - it was given the value of "1"; if stocking density was neither high nor low - it was given the value of " 2 "; and if density was low - it was given the value of " 3 ". This experiment was carried out at a selected farm for fattening chickens. Measurement took place on the $10^{\text {th }}$ and $20^{\text {th }}$ day of chickens' life. The monitored hall was of dimensions 100 $\times 10 \mathrm{~m}$ with 17,280 chickens stocked. The hall was put into operation in the late 1960s. Fresh air is supplied through holes in the side hall walls. The ventilation is provided by 5 ceiling fans with a capacity of $13,800 \mathrm{~m}^{3} \cdot \mathrm{h}^{-1}$ and 3 wall fans with a capacity of $35,000 \mathrm{~m}^{3} \cdot \mathrm{h}^{-1}$. To ensure appropriate ventilation, the standalone operation of ceiling fans is sufficient. The litter consisted of $3.5 \mathrm{~kg}$ of chopped straw per $1 \mathrm{~m}^{2}$ of the floor area. The feed system consisted of bowl feeders and water nipples. Outdoor and indoor temperatures were monitored by means of Comet logger R 3120, and the non-contact thermometer Raytek Raynger ST was used for the litter temperature measurement. The guide TP8S thermographic camera with a display range of 8-14 $\mu \mathrm{m}$ was used for determining the stocking density. The hall was divided into 256 squares. Litter temperature maps, litter quality, and stock density were processed in a Surfer program for creation of maps of measured values in the hall area. The obtained data were statistically processed in MS Excel and Statistica. By means of these programs, the mean values and the P-value of relationship were calculated from the measured data, and regression was determined.

\section{Results and discussion}

Table 1 shows the average values of the monitored indicators. Although it was the end of winter, significant differences in temperature and air humidity were observed during the monitored periods at various hall locations.

Table $\mathbf{1}$ Measured values of the selected indicators
\begin{tabular}{|l|c|c|}
\hline HALL 2 & $\mathbf{1 0}^{\text {th }}$ day & $\mathbf{2 0}^{\text {th }}$ day \\
\hline \hline Mean outdoor temperature in ${ }^{\circ} \mathbf{C}$ & -0.4 & 0.1 \\
\hline Mean rH in \% outside & 69.3 & 75.7 \\
\hline Mean indoor temperature in ${ }^{\circ} \mathbf{C}$ & 29.8 & 23.8 \\
\hline Mean rH in \% in the hall & 35.6 & 58.8 \\
\hline Mean litter temperature in ${ }^{\circ} \mathbf{C}$ & 25.8 & 25.5 \\
\hline Mean litter quality & 1.6 & 1.5 \\
\hline Mean stock density & 1.1 & 2.1 \\
\hline Chicken amount in pcs & 17,021 & 16,895 \\
\hline
\end{tabular}

It can be seen from Table 1 that, despite the winter season, the outside air temperature on the $10^{\text {th }}$ and $20^{\text {th }}$ day did not differ considerably $\left(0.5^{\circ} \mathrm{C}\right)$; however, there was a significant increase in relative humidity (6.4\%). This low temperature and high relative air humidity did not occur in the microclimate conditions in the breeding hall. Fig. 1 shows the temperature on the $10^{\text {th }}$ day.

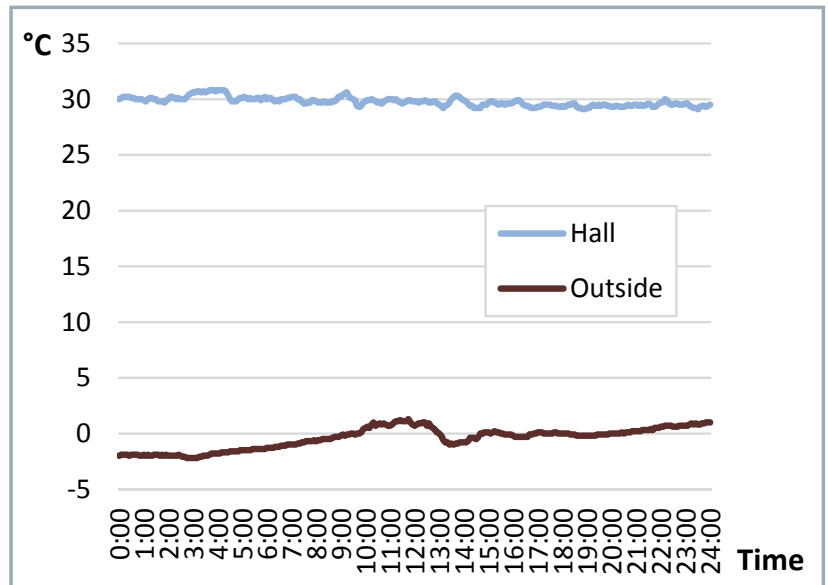

Fig. 1 Air temperature on the $10^{\text {th }}$ day

Fig. 2 shows the relative air humidity rate (\%) during the measurement of the litter temperature in the hall on the $10^{\text {th }}$ day. The outside mean air temperature was $-0.4{ }^{\circ} \mathrm{C}$, but the relative external air humidity was $69.3 \%$ and increased further up to $91.1 \%$ of relative air humidity during the day. This means that it was necessary to limit the ventilation to a minimum, but also to keep the levels of harmful gases in the hall atmosphere at safe values. By continuous reduction in the light intensity, chickens' activity in the hall decreased. After the decrease in external relative humidity, the ventilation was set to standard operation.

Fig. 3 shows the air temperature inside and outside the hall during the litter temperature measurement on the $20^{\text {th }}$ day. The outdoor mean air temperature was $0.1^{\circ} \mathrm{C}$. 


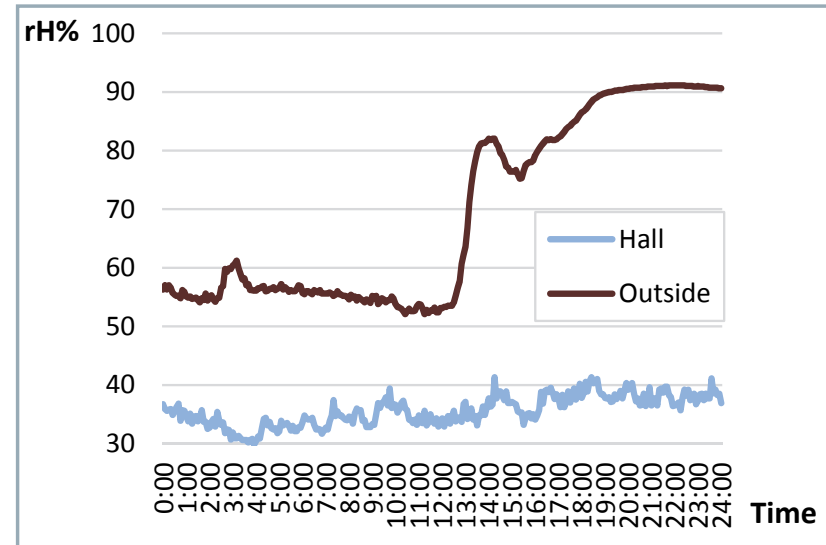

Fig. 2 Relative air humidity on the $10^{\text {th }}$ day

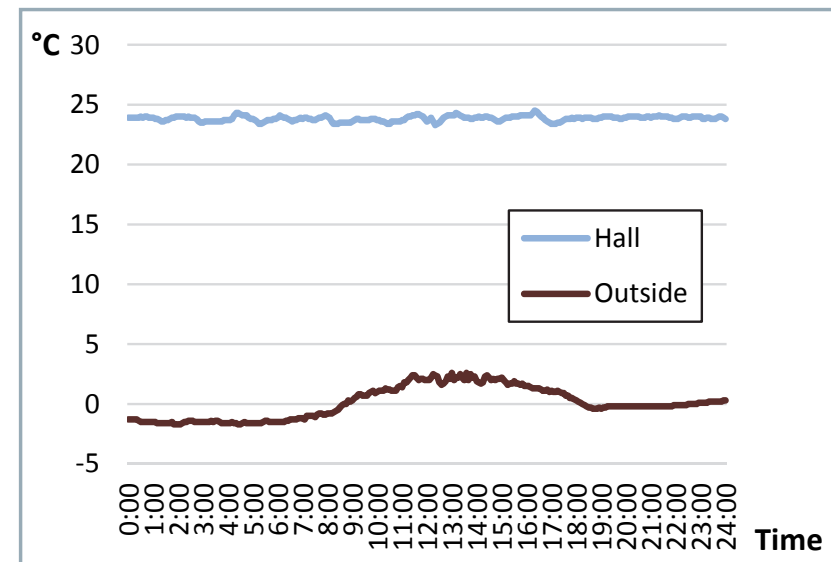

Fig. 3 Air temperature on the $20^{\text {th }}$ day

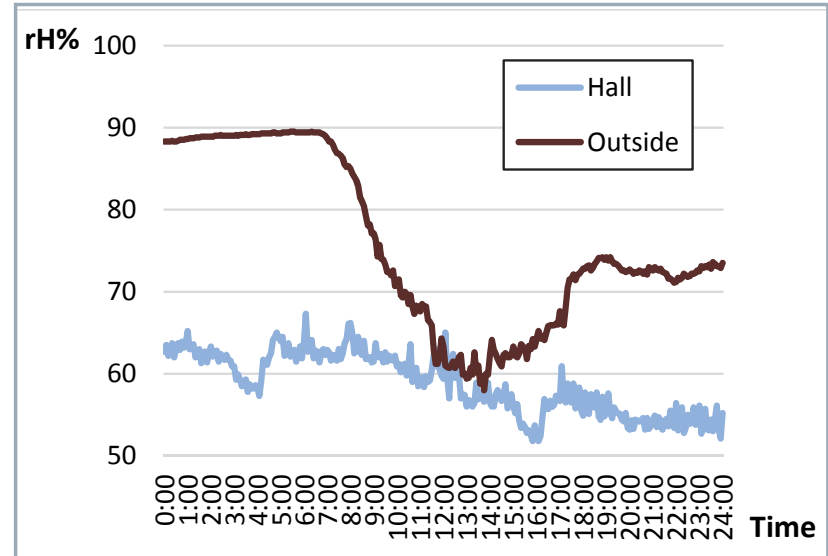

Fig. 4 Relative air humidity on the $20^{\text {th }}$ day

Fig. 4 shows the relative humidity of the air for 24 hours inside and outside the hall. The outside mean relative humidity was $75.7 \%$. The maximum value was recorded in the morning, up to $91.1 \%$. This means that it was once again necessary to reduce the ventilation operation to a minimum, but also to keep the limits of harmful gases in the hall atmosphere at safe values.

Figs 5 and 6 show the map of the temperature areas of litter in the hall on the $10^{\text {th }}$ and $20^{\text {th }}$ day of chickens' life. It is evident from the figures that on the $10^{\text {th }}$ day, the lower temperature of the bed started to occur in some places due to higher moisture (see the temperature range). On the $20^{\text {th }}$ day, cold areas can be identified due to high moisture caused by the leakage of water from water nipples. By comparing the $P$ values and the level of significance $\alpha(0.05)$, we find that the $P$ value $(0.024)<\alpha(0.05)$, which means that there is a statistical dependence between the litter temperatures on the $10^{\text {th }}$ and $20^{\text {th }}$ day.

Figs 7 and 8 show the quality map of the litter. According to these figures, the litter quality on the $10^{\text {th }}$ day ranged

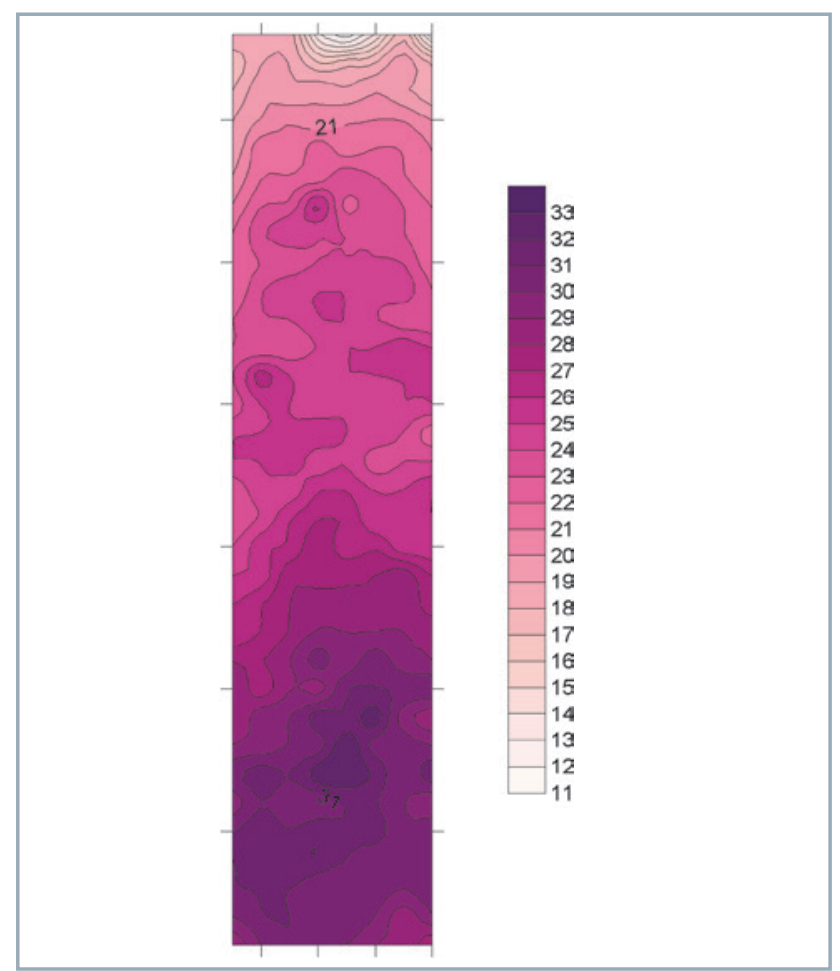

Fig. 5 Thermographic map of the litter on the $10^{\text {th }}$ day

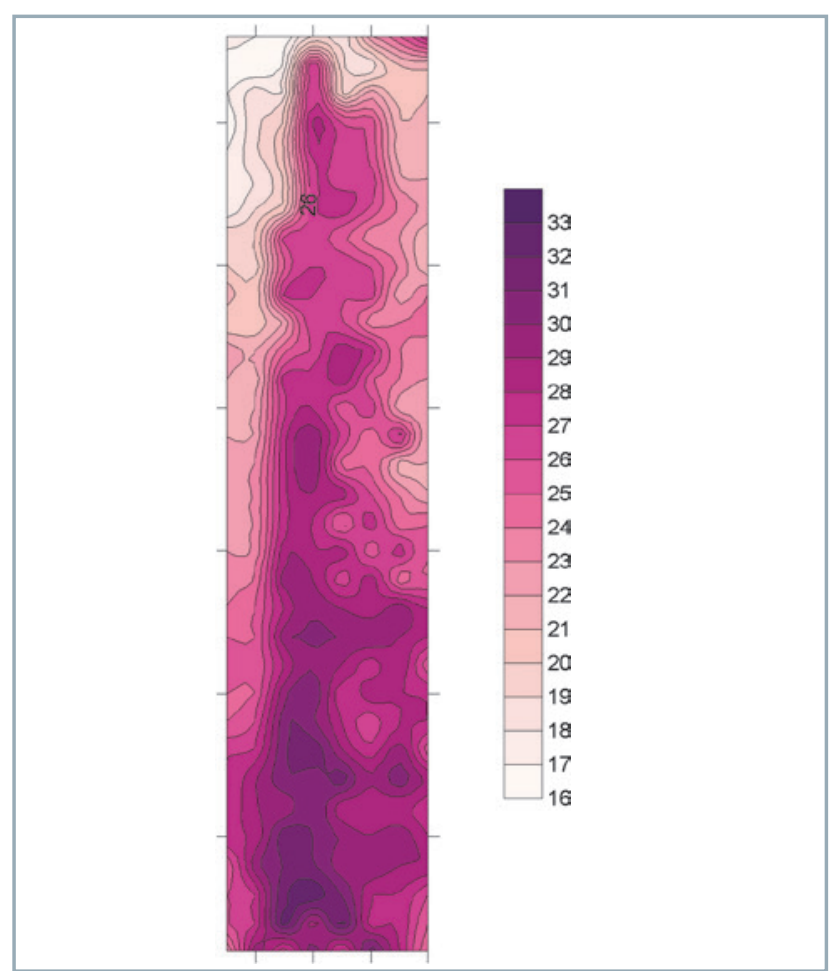

Fig. 6 Thermographic map of the litter on the $20^{\text {th }}$ day 


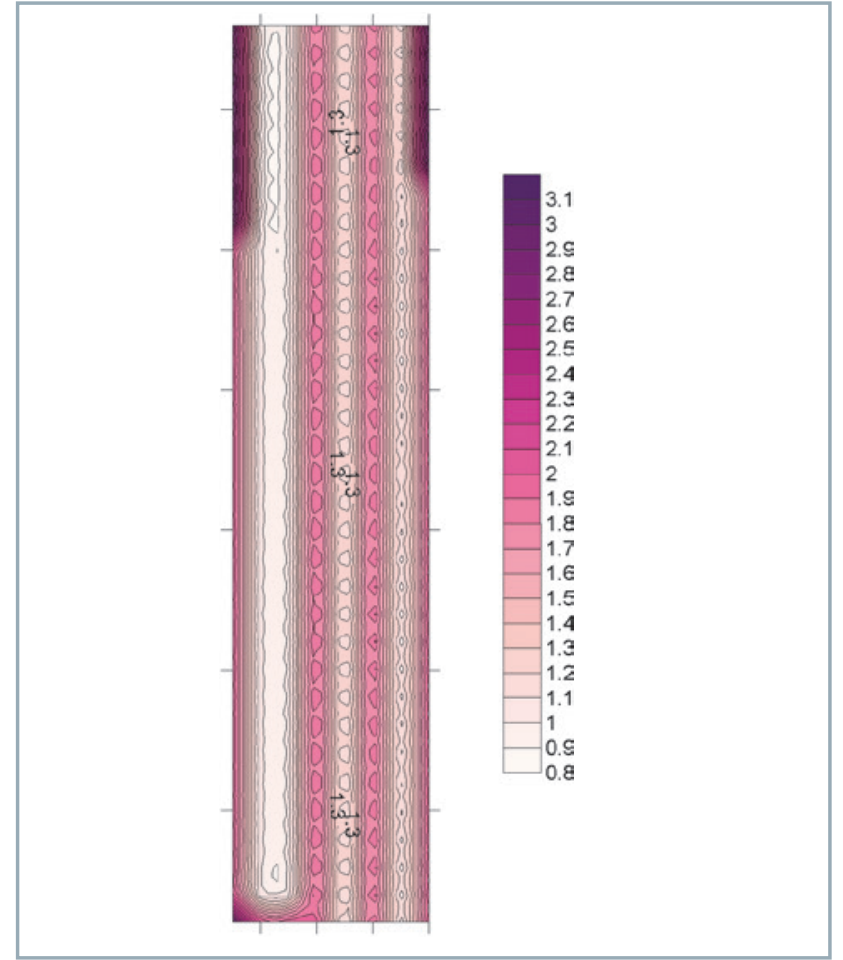

Fig.7 Quality map of the litter on the $10^{\text {th }}$ day

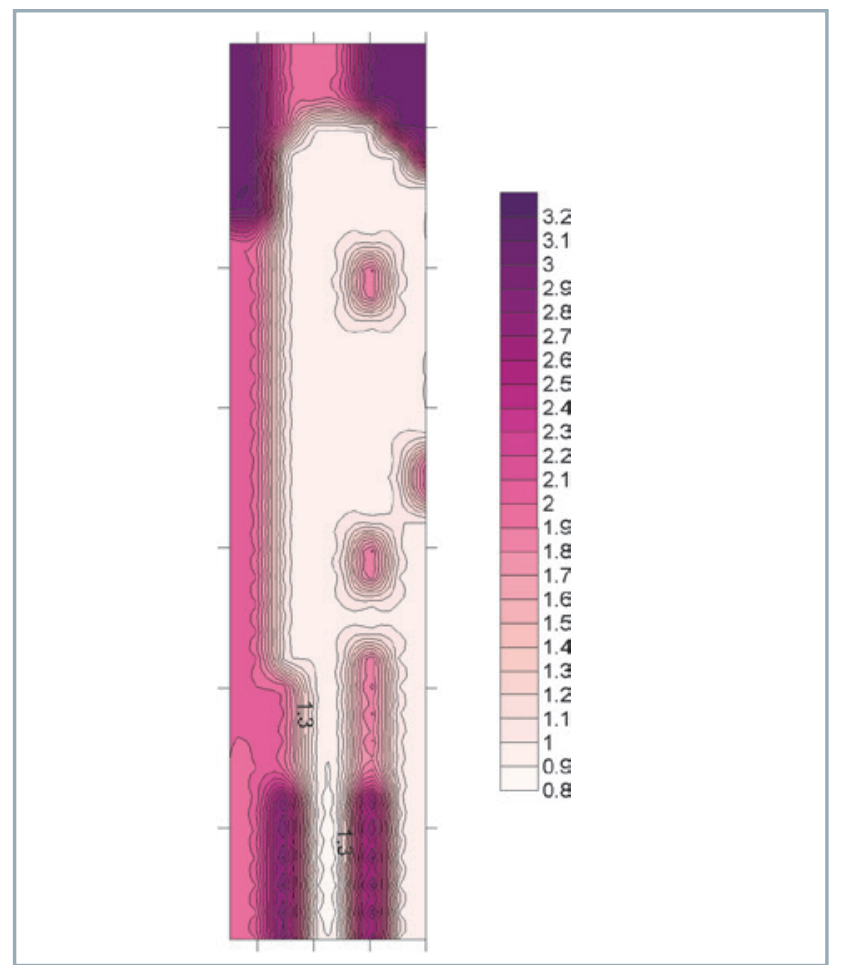

Fig. 8 Quality map of the litter on the $20^{\text {th }}$ day

between 1 and 2 . On the $20^{\text {th }}$ day, there were clearly visible places with lower litter quality, caused by water leakage from water nipples. Chickens did not stay in those spots. By comparing the $P$ values in hall 2 on the $10^{\text {th }}$ and $20^{\text {th }}$ day, we found that the $P$ value $(0.018)<\alpha(0.05)$, meaning that there is a statistical dependence between the litter quality on the $10^{\text {th }}$ and $20^{\text {th }}$ day.

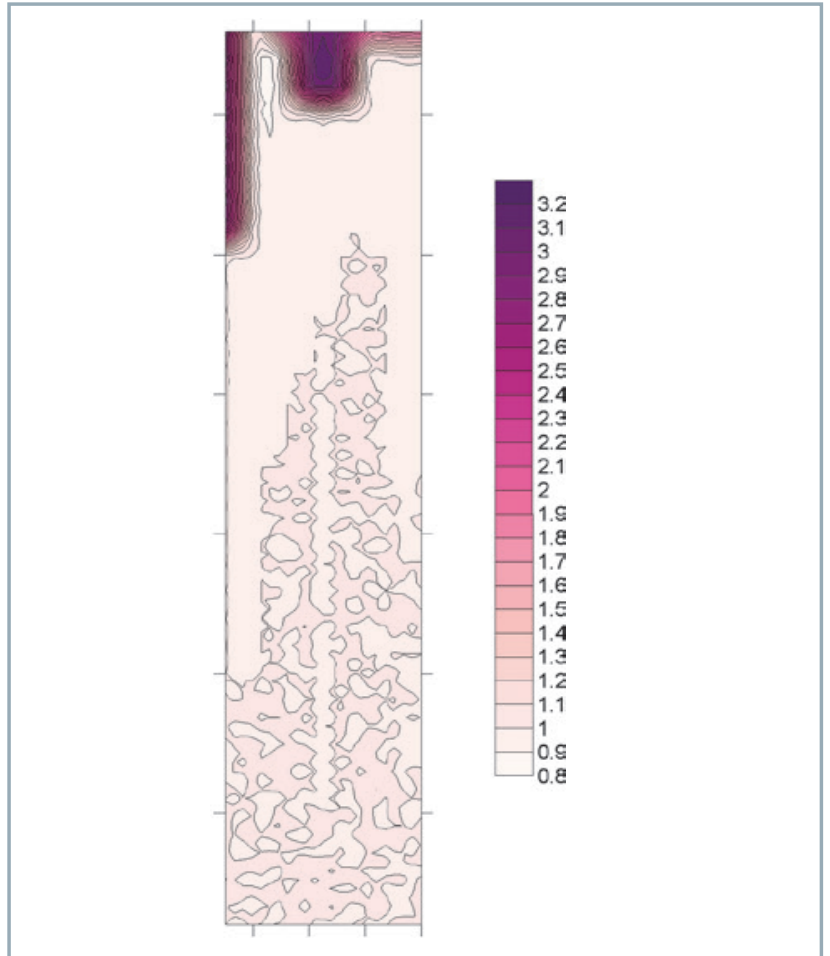

Fig. 9 Density map on the $10^{\text {th }}$ day in $\mathrm{m}^{2}$

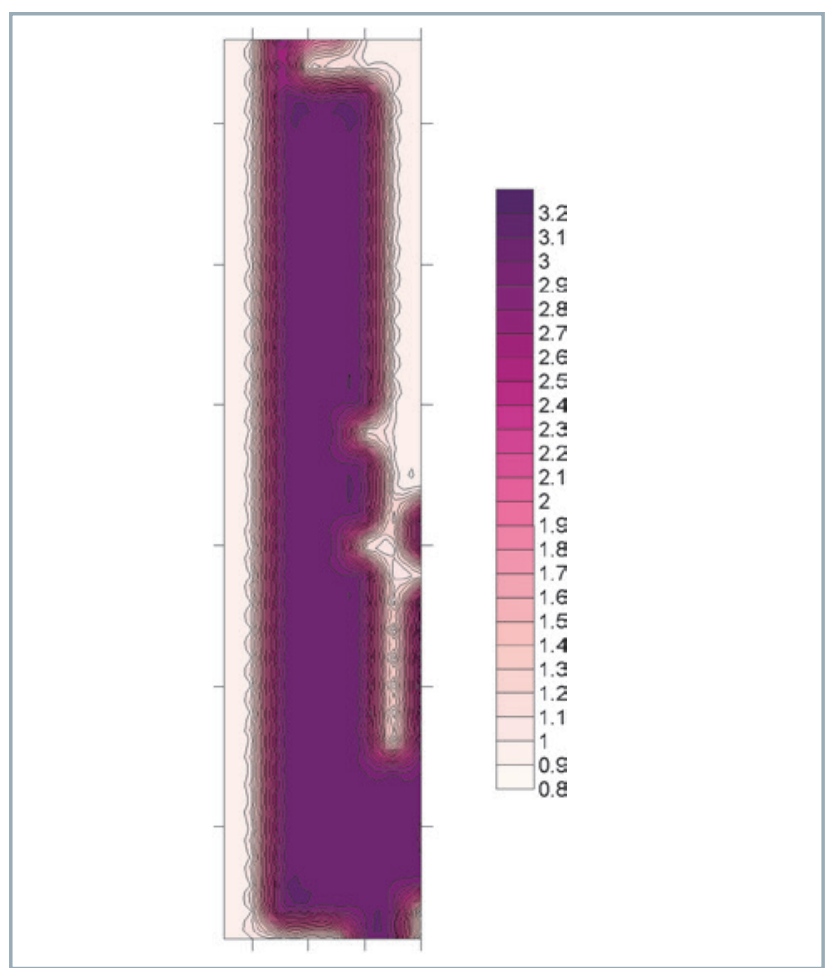

Fig. 10 Density map on the $20^{\text {th }}$ day in $\mathrm{m}^{2}$

In Fig. 9, we can see that the stocking density on the $10^{\text {th }}$ day was evenly distributed across the hall, but with a high concentration in the flock. Fig. 10 shows that chickens were particularly gathering at the hall walls on the $20^{\text {th }}$ day. When comparing the quality and density map on the $20^{\text {th }}$ day, we can see that the chickens were distributed over the whole hall area, except for the places near water nipples. However, due to the lack of space, fattening chickens occurred in 
locations which were greatly moistened. Comparing the $P$ values and the level of significance $\alpha(0.05)$, we found that the $P$ value $(0.12)<\alpha(0.05)$, meaning that there is no statistical dependence between the stocking density on the $10^{\text {th }}$ and $20^{\text {th }}$ day of chickens' life.

If the litter quality is quickly degraded due to malfunctioning of water nipples, the chickens are looking for places where they would feel comfortable. Since it was the end of winter, it is clear from the measured data, as well as according to Tančin et al. (2013), that the recommended temperatures were not exceeded. The issue of high humidity requires the knowledge of regulation of the air ventilation system. It is important to continuously monitor the air quality in the hall in order not to exceed the values of pollutants in the air and to minimise the activity of the chickens in the hall. The litter moisture exceeded the values recommended by Butcher and Miles (2015) in some locations. Those places were avoided by chickens; however, they moved also to the areas with high moisture due to lack of space in the hall. Thereby, it is necessary to focus the attention on proper operation of water nipples.

\section{Conclusions}

The aim of our work was to observe the improvement possibilities for the welfare of broiler chickens during fattening. On the basis of results, we pointed out their influence on litter quality and stocking density. The end of winter in Slovakia was characterised by minimal differences between daytime and night time temperatures. However, the relative humidity of the outside air was very high, which, in the case of intense ventilation, could also have a rapid influence on the humidity in the hall.

The obtained results show that:

- the impact of litter temperature on its quality on the $10^{\text {th }}$ day manifest high dependence $(R=0.622)$;

- the impact of density on the litter quality on the $10^{\text {th }}$ day manifest high dependence $(R=0.916)$;

- the impact of temperature on litter density on the $10^{\text {th }}$ day manifest high dependence $(R=0.711)$;

- the impact of litter temperature on its quality on the $20^{\text {th }}$ day manifest dependence $(R=0.421)$;

- the impact of density on the quality of litter on the $20^{\text {th }}$ day manifest low dependence $(R=0.392)$;

- the influence of temperature on the litter density on the $20^{\text {th }}$ day manifest low dependence $(R=0.362)$;

- the statistical dependence $P(0.024)<\alpha(0.05)$ was found between the temperature of the litter on the $10^{\text {th }}$ and $20^{\text {th }}$ day of chickens' life;

- the statistical dependence $P(0.018)<\alpha(0.05)$ was found between the quality of the litter on the $10^{\text {th }}$ and $20^{\text {th }}$ day;

- the statistical dependence $P(0.12)<\alpha(0.05)$ was not found between the stocking density on the $10^{\text {th }}$ and $20^{\text {th }}$ day of chickens' age.

From the aforementioned data, it is evident that, until the $10^{\text {th }}$ day, there is a strong dependence between litter temperature, its density and quality. On the $20^{\text {th }}$ day, there is a low dependence between the litter temperature, its density and quality.

In regard to welfare improving, we recommend to pay attention to the reliability of water nipples during the fattening cycle.

\section{References}

BESSEI, W. 2006. Welfare of broilers: A review. In World's Poultry Science Journal, vol. 62, no. 3, pp. 455-466.

BUTCHER, G. D. - MILES, R. D. 2015. Causes and prevention of wet litter in broiler houses. Publication no. VM99. Available at: <https:// edis.ifas.ufl.edu/pdffiles/VM/VM02000.pdf>

COMMUNICATIONfrom theCommissiontotheEuropeanParliament, the Council and the European Economic and Social Committee on the European Union strategy for the protection and welfare of animals 2012-2015. 2012. Available at: http://eur-lex.europa.eu/resource. html?uri=cellar:57576a43-59e3-4e99-aa3a-517b34804bc2.0003.03/ DOC_2\&format=PDF

COUNCIL DIRECTIVE 2007/43/EC of 28 June 2007 laying down minimum rules for the protection of chickens kept for meat production. Available at: http://eur-lex.europa.eu/legalcontent/ EN/TXT/PDF/?uri=CELEX:32007L0043\&from=EN

GOVERNMENT REGULATION of the Slovak Republic no. 275/2010 of 9 June 2010 laying down the minimum rules for protection of broilers raised for meat production. Available at: http://epi.sk/zz/2010-275 KARANDUŠOVSKÁ, I. - POGRAN, Š. - KNÍŽATOVÁ, M. 2009. Assessment of the Production of Pollutants in Dairy and Poultry Breeding Facilities. Nitra: SPU, 170 pp. ISBN 978-80-552-0302-7. (In Slovak: Posudzovanie produkcie škodlivín $v$ objektoch pre chov dojníc a hydiny).

KASHIHA, M. - PLUK, A. - BAHR, C. - VRANKEN, E. - BERCKMANS, D. 2013. Development of an early warning system for a broiler house using computer vision. In Biosystems Engineering, vol. 116, no. 1, pp. 36-45.

KNIZŽATOVÁ, M. - MIHINA, Š. - KARANDUŠOVSKÁ, I. - ORSÁG, J. ŠOTTNÍK, J. 2009. Concentrations and emissions of ammonia and greenhouse gases in broiler chicken housing in summer and their dependence on selected properties of litter. In Acta Technologica Agriculturae, vol. 12, no. 1, pp. 1-5.

POGRAN, Š. - BIEDA, W. - GÁLIK, R. - LENDELOVÁ, J. - ŠVENKOVÁ J. 2011. Quality of the Indoor Environment of Housing Facilities. Nitra: SPU v Nitre, 242 pp. ISBN 978-80-552-0557-1. (In Slovak: Kvalita vnútorného prostredia ustajňovacích objektov).

REICHSTÄDTEROVÁ, T. - LENDELOVÁ, J. - MIHINA, Š. - POGRAN, Š. BOŠANSKÝ, M. - ŽITŇÁK, M. 2013. Assessment of hygienic criteria of building envelope in poultry housing. In Trends in Agricultural Engineering 2013. Prague: Czech University of Life Sciences Prague, pp. 542-546. ISBN 978-80-123-2388-9.

RITZ, W. C. - FAIRCHILD, B. D. - LACY, M. P. 2009. Litter Quality and Broiler Performance. University of Georgia. Bulletin 1267. Available at: https://athenaeum.libs.uga.edu/bitstream/ handle/10724/12466/B1267.pdf? sequence $=1$ \&isAllowed $=y$

ROSS BROILER MANAGEMENT MANUAL. 2009. Available at: http:// en.aviagen.com/assets/Tech_Center/Ross_Broiler/Ross_Broiler_ Manual_09.pdf>

TANČIN, V. - APOLEN, D. - BOTTO, L.. - BRESTENSKÝ, V. - BROUČEK, J. - DAŇO, J. - DEMO, P. - HUBA, J. - KRUPA, E. - KRUPOVÁ, Z. MAČUHOVÁ, L. - MARGETÍN, M. - MARGETÍNOVÁ, J. - ORAVCOVÁ, M. - POLÁK, P. - RAFAY, J. - SLAMEČKA, J. - TOMKA, J. 2013. Livestock Farming in Marginal Areas. Publishing: Centrum výskumu živočíšnej výroby Nitra, 170 pp. ISBN 978-80-89418-26-8. (In Slovak: Chov hospodárskych zvierat v marginálnych oblastiach).

WEAVER, W. D. Jr. - MEIJERHOF, R. 1991. The effect of different levels of relative humidity and air movement on litter conditions, ammonia levels, growth, and carcass quality for broiler chickens. In Poultry Science, vol. 70, no. 4, pp.746-755.

WEBSTER, J. 1994. Animal Welfare. A Cool Eye Towards Eden. In Blackwell Science Ltd. 259 pp. ISBN 80-238-4086-X. 